\title{
Improved Nutrient PARAmeters FOR Modeling Diffuse Pollution IN THE TROPICS
}

\author{
M. A. C. Caiado, C. D. Heatwole
}

\begin{abstract}
Nonpoint-source (NPS) or diffuse pollution is a major environmental problem in developed countries, and modeling is an important tool used to evaluate the effectiveness of pollution control measures. The use of NPS models in the tropics usually involves the application of models developed for temperate regions with little, if any, adaptation to tropical conditions. In this article, we provide a synthesis of the literature values from studies in the tropics, using the GLEAMS model as a reference for the comparable values used in representing temperate conditions. We found that values for the carbon to nitrogen (C:N) ratio, potentially mineralizable nitrogen to total nitrogen ratio $\left(\mathrm{N}_{0} / \mathrm{N}_{\text {total }}\right)$, and base $\mathrm{NO}_{3}-\mathrm{N}$ and $\mathrm{NH}_{4}-\mathrm{N}$ concentrations representative of tropical soils were all different from the values considered appropriate for temperate soils. Relationships between phosphorus pools in tropical soils and in phosphorus sorption parameters likewise were different from those used in GLEAMS, with the exception that the GLEAMS ratio between labile and organic phosphorus in highly weathered soils was found to be comparable to data specific for tropical soils.
\end{abstract}

Keywords. Agroecosystem, Diffuse pollution, GLEAMS, Model, Nitrogen, Nonpoint pollution, Nutrients, Phosphorus, Tropical soils, Tropics.

$\mathrm{T}$ he major portion of nonpoint-source (NPS) water pollution originates from a broad range of human activities from which the pollutants have no obvious point of entry into receiving waters. Agricultural activities can be a major source of NPS pollution, with the discharge of sediments, pesticides, nutrients, and microorganisms impacting stream water quality (EPA, 2003). NPS pollution is a major environmental problem in developed countries, and is growing as an issue of concern in tropical developing countries as areas used for subsistence or lowintensity agriculture have transitioned to high-technology agriculture with increased use of fertilizers and pesticides. The tropics comprise about $36 \%$ of the earth surface, and characteristics differ from temperate areas in many aspects. These differences must be considered when practices developed in temperate areas to control NPS pollution are applied in the tropics.

Modeling is an important tool used to evaluate the effectiveness of NPS pollution control measures, and NPS models are commonly used in developed countries for environmental evaluation and management. However, the use of NPS models is limited in the tropics and usually involves the application of models developed for temperate conditions with only minor, if any, adaptation to tropical conditions. Ecosystem

Submitted for review in October 2008 as manuscript number SW 7772; approved for publication by the Soil \& Water of ASABE in April 2009.

The authors are Marco A. C. Caiado, Professor, Coordenadoria de Saneamento Ambiental, Instituto Federal de Educaçao, Ciência e Technológica do Espírito Santo (IFES), Vitória, Brazil, and Conrad D. Heatwole, ASABE Member Engineer, Associate Professor, Department of Biological Systems Engineering, Virginia Tech, Blacksburg, Virginia. Corresponding author: Conrad D. Heatwole, Department of Biological Systems Engineering, 301 Seitz Hall, Virginia Tech, Blacksburg, VA 24061; phone: 540-231-4858; fax: 540-231-3199; e-mail: heatwole@vt. edu. models commonly include regression relationships and default or base parameter values that represent the conditions of the region for which the model was developed. While some values can be specified as inputs, others are part of the model code and cannot be readily changed. It is critical to define the characteristic parameters and default values that represent nutrient dynamics in tropical soils so that they can be integrated into NPS models to better represent rate processes and base conditions in predicting nutrient fate and transport.

The objective of this study was to determine from the literature: values for the carbon to nitrogen $(\mathrm{C}: \mathrm{N})$ ratio of soil organic matter, the ratio of potential mineralizable to total nitrogen in the soil $\left(\mathrm{N}_{0} / \mathrm{N}_{\text {total }}\right)$, base soil nitrate $\left(\mathrm{NO}_{3}-\mathrm{N}\right)$ and ammonium $\left(\mathrm{NH}_{4}-\mathrm{N}\right)$ concentrations, soil phosphorus sorption, and the relationships between the main pools of phosphorus $(\mathrm{P})$ in tropical soils. The Groundwater Loading Effects of Agricultural Management Systems (GLEAMS) model (Knisel and Davis, 1999), which was developed with data from North America, was used as a reference in comparison with the values and relationships sought here in a synthesis of results of studies in tropical conditions.

\section{Carbon to Nitrogen Ratio}

The C:N ratio for tropical soils was evaluated using published data from 13 studies. Data of organic $\mathrm{C}$ and total nitrogen from Brazil (Araujo et al., 2001; D'Andrea et al., 2004; Sampaio et al., 1990; Van Wambeke, 2003), Dominica, Guadeloupe and Santa Lucia (Chotte et al., 1998), Malaysia (Mubarak et al., 2001), Hawaii (Neff et al., 2000), Thailand, Sudan, and Zambia (Van Wambeke, 2003), Australia (O'Connel and Rance, 1999), Venezuela (San Jose et al., 2003), Nigeria (Wong et al., 1987), Martinique (Neff et al., 2000), Colombia (Phiri et al., 2001), Ethiopia (Solomon et al., 2002), and Kenya (Warren and Kihanda, 2001) were included in this analysis. 
Table 1. Area and mean $\mathrm{C}: \mathrm{N}$ ratio for different soil orders in the tropics.

\begin{tabular}{cccc}
\hline & \multicolumn{2}{c}{ Total Area in the Tropics[a] } & $\begin{array}{c}\text { Mean } \\
\text { Soil }\end{array}$ \\
\cline { 2 - 3 }$\left(10^{6}\right.$ ha $)$ & $(\%)$ & C:N Ratio[b] \\
\hline Oxisols & 525 & 35.3 & 13.0 \\
Ultisols & 413 & 27.7 & 13.3 \\
Inceptisols & 226 & 15.2 & 12.3 \\
Alfisols & 53 & 3.6 & 8.0 \\
Spodosols & 19 & 1.3 & 44.7 \\
Vertisols & 5 & 0.3 & 12.3 \\
Entisols & 212 & 14.2 & -- [c] \\
Histosols & 27 & 1.8 & -- [c] \\
Mollisols & 7 & 0.5 & -- [c] \\
Aridisols & 2 & 0.1 & $--[\mathrm{c}]$
\end{tabular}

[a] From Lal (1995).

[b] Based on data from: Araujo et al. (2001), D'Andrea et al. (2004), Sampaio et al. (1990), Van Wambeke (2003), Chotte et al. (1998), Mubarak et al. (2001), Neff et al. (2000), O'Connel and Rance (1999), San Jose et al. (2003), Wong et al. (1987), Phiri et al. (2001), Solomon et al. (2002), and Warren and Kihanda (2001).

[c] No data for these soil orders.

A summary of the mean $\mathrm{C}: \mathrm{N}$ ratio by soil order is shown in table 1 along with the total area of each soil order in the tropics. The area-weighted mean $\mathrm{C}: \mathrm{N}$ value (considering only soil orders with data) is 13.24 , which is comparable to values from four other large datasets (Tognon et al., 1998; Post and Pastor, 1985; Sanchez et al., 1982; ISRIC, 2003). For comparison, the default $\mathrm{C}: \mathrm{N}$ ratio in GLEAMS is set at 10:1. From the data summarized here, a value of 13.0 is suggested for representing the $\mathrm{C}: \mathrm{N}$ ratio in tropical soils. This value is clearly representative of the three primary soil orders that comprise over $78 \%$ of soils in the tropics. However, in areas with Spodosols, Alfisols, or one of the soil orders without data in table 1 , the applicability of either value as a default $\mathrm{C}: \mathrm{N}$ ratio should be questioned.

\section{Potentially Mineralizable Nitrogen $\left(\mathrm{N}_{\mathbf{0}}\right)$}

Stanford and Smith (1978) used data of 62 soils from eight soil orders (Alfisols, Aridisols, Entisols, Inceptisols, Mollisols, Spodosols, Ultisols, and Vertisols), all from temperate sites in North America, and observed an average ratio of $\mathrm{N}_{0} / \mathrm{N}_{\text {total }}$ of 0.165 . These data were used in defining the default value of potentially mineralizable $\mathrm{N}$ in GLEAMS. The average ratio of $\mathrm{N}_{0} / \mathrm{N}_{\text {total }}$ for tropical soils was calculated using 27 data values from soils in Venezuela (San Jose et al., 2003), Colombia, Brazil, Costa Rica, Peru (Motavalli et al., 1995), and Australia (Campbell et al., 1981). The data include samples of four Ultisols from Venezuela, two Vertisols and one Andisol from Colombia, one Vertisol and two Andisols from Costa Rica, one Mollisol and four Oxisols from Brazil, and five soils from Australia. All data were from samples collected to a depth of $30 \mathrm{~cm}$.

Table 2 shows summary statistics of the $\mathrm{N}_{0} / \mathrm{N}_{\text {total }}$ ratio of the temperate and tropical soil datasets. High variation in the data, evidenced by the high values of range and standard deviation (SD), is seen in both data sets. For the tropical data, the confidence interval of the mean was calculated as 0.140 $\pm 0.022(\alpha=0.05)$, and 0.14 was considered the most appropriate value to represent the $\mathrm{N}_{0} / \mathrm{N}_{\text {total }}$ ratio in tropical soils.
Table 2. Summary statistics of $\mathbf{N}_{0} / \mathbf{N}_{\text {total }}$ ratio for temperate and tropical soils.

\begin{tabular}{lccccc}
\hline Region & Count & Mean & SD & Min. & Max. \\
\hline Temperate $^{[a]}$ & 62 & 0.165 & 0.068 & 0.046 & 0.405 \\
Tropical $^{[b]}$ & 27 & 0.140 & 0.059 & 0.062 & 0.303 \\
\hline
\end{tabular}

[a] Source: Stanford and Smith (1978).

[b] Sources: San Jose et al. (2003), Motavalli et al. (1995), and Campbell et al. (1981).

\section{Nitrate AND Ammonia}

The default value for nitrate concentration in GLEAMS is $5 \mu \mathrm{g} \mathrm{NO} \mathrm{N}_{3}-\mathrm{N} / \mathrm{g}$ soil in all horizons, while the ammonium value is set as $2 \mu \mathrm{g} / \mathrm{g}$ soil. Nine studies with values of nitrate and five with values of ammonium at different depths and locations were used to estimate values for the tropics. The nine studies for nitrate were by D'Andrea et al. (2004) in Brazil, Phiri et al. (2001) in a Colombian Inceptisol, Deare et al. (1995) in Trinidad, Mekonnen et al. (1997) in western Kenya, Arora and Juo (1982) in Nigeria, Shepherd et al. (2001) in the highlands of western Kenya, Wild (1972) in northern Nigeria, Hartemink et al. (1996) in the subhumid highlands of Kenya, and Strong et al. (1998) in New South Wales, Australia. Concentrations of $\mathrm{NO}_{3}-\mathrm{N}$ and $\mathrm{NH}_{4}-\mathrm{N}$ were averaged by soil order and the area-weighted mean determined based on the prevalence of each soil order in the tropics (table 3 ).

The mean and confidence interval for $\mathrm{NO}_{3}-\mathrm{N}$ concentration for the entire dataset was $11.33 \pm 1.07(\alpha=0.05)$, and the area-weighted mean is $10.34 \mu \mathrm{g} \mathrm{NO} \mathrm{N}_{3}-\mathrm{N} / \mathrm{g}$ soil. From these data, the value of $10 \mu \mathrm{g} \mathrm{NO} \mathrm{N}_{3}-\mathrm{N} / \mathrm{g}$ soil is suggested as a more representative default value of $\mathrm{NO}_{3}-\mathrm{N}$ concentration for tropical soils. While the dataset is small, the higher value of $\mathrm{NO}_{3}-\mathrm{N}$ is supported by the work of Sierra et al. (2003), who found that positive charges in tropical soils retarded nitrate movement, resulting in higher concentrations before losses by leaching.

The data on $\mathrm{NH}_{4}-\mathrm{N}$ concentrations were also grouped by sample depth, and summary statistics are shown in table 4. High variation in the dataset is evident in every soil layer, but it is clear that values are significantly higher than the $2 \mu \mathrm{g}$ $\mathrm{NH}_{4}-\mathrm{N} / \mathrm{g}$ soil default value used in GLEAMS. The mean values varied from $25.81 \mu \mathrm{g} \mathrm{NH} 4-\mathrm{N} / \mathrm{g}$ soil in the $1-10 \mathrm{~cm}$ layer to $9.62 \mu \mathrm{g} \mathrm{NH}-\mathrm{N} / \mathrm{g}$ soil in the $40-80 \mathrm{~cm}$ layer depth. Silva and Vale (2000) also found higher values of $\mathrm{NH}_{4}-\mathrm{N}$ than those typical for temperate conditions. They observed values of ammonium concentration ranging from 10 to $23 \mu \mathrm{g}$ $\mathrm{NH}_{4}-\mathrm{N} / \mathrm{g}$ soil in the superficial layer of five soils from the southeastern region of Brazil.

One of the main causes for higher ammonium concentration in tropical soils is the inhibition of nitrification in acidic

Table 3. Mean $\mathrm{NO}_{3}-\mathrm{N}$ and $\mathrm{NH}_{4}-\mathrm{N}$ concentrations for some soil orders in the tropics.

\begin{tabular}{|c|c|c|c|c|}
\hline \multirow[b]{2}{*}{ Soil } & \multicolumn{2}{|c|}{ Total Area in the Tropics } & \multirow{2}{*}{$\begin{array}{c}\mathrm{NO}_{3}-\mathrm{N}[\mathrm{a}],[\mathrm{b}] \\
(\mu \mathrm{g} / \mathrm{g} \text { soil })\end{array}$} & \multirow{2}{*}{$\begin{array}{l}\mathrm{NH}_{4}-\mathrm{N}[\mathrm{a}] \\
(\mu \mathrm{g} / \mathrm{g} \text { soil })\end{array}$} \\
\hline & $\left(10^{6} \mathrm{ha}\right)$ & $(\%)$ & & \\
\hline Oxisols & 525 & 35.3 & 12.5 & 18.8 \\
\hline Ultisols & 413 & 27.7 & 8.6 & 19.1 \\
\hline Inceptisols & 226 & 15.2 & 7.7 & 19.2 \\
\hline Alfisols & 53 & 3.6 & 14.1 & -- \\
\hline \multicolumn{3}{|c|}{ Area-weighted average: } & 10.34 & 18.98 \\
\hline
\end{tabular}

[a] Sources: D'Andrea et al. (2004), Phiri et al. (2001), Deare et al. (1995), Arora and Juo (1982), and Strong et al. (1998).

[b] Sources: Mekonnen et al. (1997), Shepherd et al, (2001), Wild (1972), and Hartemink et al. (1996). 
Table 4. Summary statistics of $\mathrm{NH}_{4}-\mathrm{N}$ concentration in tropical soils. [a]

\begin{tabular}{ccrrrr}
\hline \multirow{2}{*}{$\begin{array}{c}\text { Depth } \\
(\mathrm{cm})\end{array}$} & & \multicolumn{4}{c}{$\mathrm{NH}_{4}-\mathrm{N}$ concentration $(\mu \mathrm{g} \mathrm{NH} 4-\mathrm{N} / \mathrm{g}$ soil $)$} \\
\cline { 3 - 6 } & Count & Mean & \multicolumn{1}{c}{$\mathrm{SD}$} & Min. & Max. \\
\hline $1-10$ & 60 & 25.81 & 30.54 & 0.00 & 156.00 \\
$10-20$ & 12 & 18.39 & 9.42 & 8.93 & 42.86 \\
$20-40$ & 42 & 14.55 & 14.63 & 4.00 & 99.00 \\
$40-80$ & 24 & 9.62 & 6.44 & 3.00 & 33.93 \\
$80-100$ & 6 & 17.26 & 2.63 & 15.18 & 21.43
\end{tabular}

[a] Sources: D'Andrea et al. (2004), Phiri et al. (2001), Deare et al. (1995), Arora and Juo (1982), and Strong et al. (1998)

soils. Sierra et al. (2003) considered the nitrification rate to be a result of factors related to soil moisture, $\mathrm{pH}$, and temperature. According to Silva et al. (1994), nitrification rates decrease sharply at a $\mathrm{pH}$ lower than 6 and are very low in soils with $\mathrm{pH}$ lower than 5 . Besides reducing the nitrification rate, low $\mathrm{pH}$ favors the formation of the ammonium cation in its equilibrium reaction with ammonia. Because low $\mathrm{pH}$ is a characteristic of tropical soils and was also typical of the soils in the studies used in this analysis, a buildup of $\mathrm{NH}_{4}-\mathrm{N}$ may be expected, accounting for the higher values of $\mathrm{NH}_{4}-\mathrm{N}$ in tropical soils.

The mean and confidence interval of $\mathrm{NH}_{4}-\mathrm{N}$ concentration for the entire dataset is $18.9 \pm 3.67(\alpha=0.05)$, while the area-weighted mean based on the distribution of soils in the tropics is $18.98 \mu \mathrm{g} \mathrm{NH}-\mathrm{N} / \mathrm{g}$ soil. For tropical conditions, a value of $19 \mu \mathrm{g} \mathrm{NH}_{4}-\mathrm{N} / \mathrm{g}$ soil is recommended as the default value of $\mathrm{NH}_{4}-\mathrm{N}$ for all soil layers.

\section{PhOSPHORUS}

The equations used in GLEAMS for calculating initial values of phosphorus were based on Sharpley et al. (1984). For the surface horizon of highly weathered soils, soil organic $\mathrm{P}$ (SORGP, $\mathrm{mg} / \mathrm{kg}$ ) is calculated as:

$$
\text { SORGP }=1130 \mathrm{TN}+44.4
$$

where $\mathrm{TN}$ is total nitrogen (\%). For the other horizons, the relationship is given by:

$$
\text { SORGP }=1464 \mathrm{TN}
$$

Sharpley et al. (1989), using data of 32 highly weathered soils (5 Alfisols, 2 Inceptisols, 3 Oxisols, 3 Spodosols, and 19 Ultisols), all with Al saturation greater than 30, derived the following equations:

$$
\text { SORGP }=1109 \mathrm{TN}+42.2
$$

Table 5. Relationships between soil organic $P$ (SORGP), organic carbon (OC), and total nitrogen (TN) for some tropical soils.

\begin{tabular}{lccc}
\hline \multicolumn{1}{c}{ Model ${ }^{[\mathrm{a}]}$} & Dataset & $\mathrm{R}^{2}$ & Eq. \\
\hline SORGP $=2.541$ OC +8.8 & Ipinmidun (1973) & 0.61 & 5 \\
SORGP $=6.904$ OC -14.3 & Condron et al. (1990) & 0.52 & 6 \\
SORGP $=777$ TN +6.0 & Condron et al. (1990) & 0.35 & 7 \\
SORGP $=3.026$ OC +23.8 & Guerra et al. (1996) & 0.28 & 8 \\
SORGP $=428 \mathrm{TN}+2.6$ & Guerra et al. (1996) & 0.51 & 9
\end{tabular}

[a] SORGP is soil organic $\mathrm{P}(\mathrm{mg} \mathrm{P} / \mathrm{kg}$ soil), TN is total nitrogen (\%), and OC is organic carbon ( $\mathrm{g} \mathrm{C} / \mathrm{kg}$ soil).

$$
\text { SORGP }=62.1 \mathrm{OC}+63.4
$$

where SORGP is organic $\mathrm{P}(\mathrm{mg} / \mathrm{kg})$, OC is organic carbon $(\%)$, and TN is total nitrogen (\%).

In our analysis, we used three datasets to calculate soil organic phosphorus (SORGP) based on organic carbon (OC) and total nitrogen $(\mathrm{TN})$. The data represent 15 soils from sites in north-eastern Brazil and Ghana (Condron et al., 1990), 13 soils from Brazil (Guerra et al., 1996), and 16 soils from northern Nigeria (Ipinmidun, 1973). Five new models derived by linear regression from these data are shown in table 5.

Equations 1 and 3 to 9 were then evaluated using the datasets of Condron et al. (1990), Guerra et al. (1996), and Ipinmidun (1973). The equations were used to calculate SORGP and the results compared with measured data through the calculation of the mean square error (MSE):

$$
\text { MSE }=\frac{\sum_{i=1}^{n}\left(r_{i}\right)^{2}}{n}
$$

where $r_{i}$ is the difference between measured and predicted values, and $n$ is the number of observations. The results are shown in table 6.

In every case, the last five models (eqs. 5 through 9) had better goodness-of-fit (MSE) than the models presented by Sharpley et al. $(1984,1989)$ (eqs. 1, 3, and 4). The equations using $\mathrm{OC}$ as an independent variable (eqs. 4, 5, 6, and 8), overall, had lower MSE than the equations based on TN. The model (eq. 6) derived from the dataset of Condron et al. (1990) is recommended for calculating organic phosphorus in tropical soils.

Labile P (CLAB) is estimated in GLEAMS as $10 \%$ of SORGP for calcareous soils, $8.7 \%$ of SORGP for slightly

\begin{tabular}{|c|c|c|c|c|}
\hline \multirow[b]{2}{*}{ Equation } & \multirow[b]{2}{*}{ Model[a] } & \multicolumn{3}{|c|}{ Mean Square Error of SORGP } \\
\hline & & Condron et al. (1990) & Guerra et al. (1996) & Ipinmidun (1973) \\
\hline 1 & $\mathrm{SORGP}=1130 \mathrm{TN}+44.4$ & 7,529 & 24,874 & -- \\
\hline 3 & $\mathrm{SORGP}=1109 \mathrm{TN}+42.2$ & $1,183,820$ & $3,234,676$ & -- \\
\hline 4 & $\mathrm{SORGP}=62.1 \mathrm{OC}+63.4$ & 774,854 & 972,396 & 144,172 \\
\hline 5 & $\mathrm{SORGP}=2.541 \mathrm{OC}+8.8$ & 3,612 & 1,358 & $37[\mathrm{~b}]$ \\
\hline 6 & SORGP $=6.904 \mathrm{OC}-14.3$ & $1,681^{[\mathrm{b}]}$ & 1,974 & 210 \\
\hline 7 & $\mathrm{SORGP}=777 \mathrm{TN}+6.0$ & $2,270^{[\mathrm{b}]}$ & 2,427 & -- \\
\hline 8 & SORGP $=3.026 \mathrm{OC}+23.8$ & 2,427 & $857^{[\mathrm{b}]}$ & 337 \\
\hline 9 & $\mathrm{SORGP}=428 \mathrm{TN}+2.6$ & 3,777 & $581^{[\mathrm{b}]}$ & -- \\
\hline
\end{tabular}
weathered soils, and $5.6 \%$ of SORGP for highly weathered soils. Most studies that report different pools of phosphorus

Table 6. Goodness-of-fit of eight models predicting soil organic P (SORGP) from total nitrogen (TN) and organic carbon $(\mathrm{OC})$ based on comparison with three datasets.

[a] SORGP is soil organic $\mathrm{P}$ (mg P/kg soil), TN is total nitrogen (\%), and OC is organic carbon (g C/kg soil).

[b] Values in italics indicate the model was derived from that dataset. 
in tropical soils considered residual $\mathrm{P}$ as one pool in which organic and inorganic recalcitrant $\mathrm{P}$ were measured together (e.g., Tokura et al., 2002; Silva et al., 2003), making it impossible to calculate total organic P. However, the studies of Guerra et al. (1996), Oberson et al. (2001), and Cardoso et al. (2003) have data that allow the calculation of the relationship between labile $\mathrm{P}$ and total organic $\mathrm{P}$. The studies comprise 28 values from different soils and land uses, mostly from Brazil. Using these data, the percentage of CLAB in relation to total organic $\mathrm{P}$ was calculated. The confidence interval for the relationship between both $\mathrm{P}$ pools was $5.24 \pm 1.75$, which encompasses the value of 5.6 used in the GLEAMS model for highly weathered soils. Thus, the relationship between both $P$ pools used in GLEAMS for highly weathered soils $(\mathrm{CLAB}=5.6 \%$ SORGP) was considered appropriate for calculating the default value of labile $\mathrm{P}$ in tropical soils.

The phosphorus sorption coefficient or $\mathrm{P}$ availability index is a variable that estimates the fraction of fertilizer $\mathrm{P}$ that remains in the labile form after a six-month incubation. It is used by GLEAMS to calculate active mineral P (PMINP) using values of labile P. Soil sorption (PSP) is calculated as follows:

$$
\mathrm{PSP}=0.46-0.0916 * \ln (\text { CLAYPCT })
$$

where CLAYPCT is clay content of the soil layer (\%).

Sharpley et al. (1989), using data of 32 highly weathered soils (5 Alfisols, 2 Inceptisols, 3 Oxisols, 3 Spodosols, and 19 Ultisols), all with Al saturation greater than 30, proposed:

$$
\text { PSP }=0.7-0.19 \log (\text { CLAYPCT })
$$

When clay is equal to or greater than $40 \%$, this equation results in negative values of PSP. Because clay content greater than $40 \%$ is common in tropical soils, the model of Sharpley et al. (1989) is not considered appropriate for PSP calculation for tropical soils.

The appropriateness of using equation 11 for tropical soils was assessed using the data from Goncalves et al. (1989), Lopez et al. (2001), and Cardoso et al. (2003). The first two studies were based on 18 soil samples and experimentally determined the value of PSP. In these studies, different amounts of fertilizer $P$ were added to soil samples, which were incubated for 180 days. The following equation was defined:

$$
\mathrm{PSP}=\left(\mathrm{P}_{\mathrm{lf}}-\mathrm{P}_{\mathrm{li}}\right) / \mathrm{P}_{\mathrm{f}}
$$

where $\mathrm{P}_{\text {lf }}$ is $\mathrm{mg} / \mathrm{kg}$ labile $\mathrm{P}$ after 180 days of incubation, $\mathrm{P}_{\mathrm{li}}$ is $\mathrm{mg} / \mathrm{kg}$ labile $\mathrm{P}$ in the control (when no $\mathrm{P}$ is added to the soil sample), and $P_{f}$ is $\mathrm{mg} / \mathrm{kg}$ labile $\mathrm{P}$ added as fertilizer. The mean value of PSP for the two datasets was 0.14 , with standard deviation of 0.07 . The appropriateness of using the mean value of PSP in the place of values calculated using equation 11 was evaluated using data from Cardoso et al. (2003), which contains measured values of CLAB and PMINP. For this evaluation, values of PMINP were calculated as:

$$
\text { PMINP = PLAB / }(\mathrm{PSP} /(1-\mathrm{PSP}))
$$

The mean square error (MSE) between measured and calculated values of PMINP was 1046 when PMINP was calculated using PSP $=0.14$ and 1566 when PSP was calculated by using equation 11 . The value of 0.14 is thus considered to be an improvement in representing PSP for highly weathered tropical soils compared to the equation used in GLEAMS based on temperate soils.

\section{Conclusions}

A synthesis of data from studies relating to nutrient dynamics in tropical soils found important differences in parameters and relationships in comparison to values derived from data in temperate soils. Specifically, differences in tropical versus temperate conditions are evident in the $\mathrm{C}: \mathrm{N}$ ratio, in the ratio of potentially mineralizable nitrogen to total nitrogen $\left(\mathrm{N}_{0} / \mathrm{N}_{\text {total }}\right)$, in soil nitrate and ammonium concentrations, in soil $\mathrm{P}$ sorption, and in the relationships between the main pools of $\mathrm{P}$ in tropical soils. The ratio between labile and organic phosphorus in highly weathered soils was found to be comparable to that in tropical soils. Improving these parameters and relationships in models concerned with predicting nutrient dynamics and nonpoint-source pollution in the landscape will result in improved representation of the processes in tropical conditions.

\section{ACKNOWLEDGEMENTS}

This work was made possible by a graduate research fellowship from the Coordenação de Aperfeiçoamento de Pessoal de Nível Superior (CAPES), Brazilian Ministry of Education; through the support of the SANREM-CRSP program of the U.S. Agency for International Development; and through the support of the USDA Cooperative State Research, Education and Extension Service under Project No. 0199804.

\section{REFERENCES}

Araujo, A. M. S., E. V. S. B. Sampaio, and I. H. Salcedo. 2001. Mineralizacao do $\mathrm{C}$ e $\mathrm{N}$ em amostras armazenadas de solos cultivados com cana de acucar ao longo de 10 anos, com e sem fertilizacao nitrogenada. Revista Brasileira de Ciencia do Solo 25: 43-53.

Arora, Y, and A. S. R. Juo. 1982. Leaching of fertilizer ions in a kaolinitic Ultisol in the high rainfall tropics: Leaching of nitrate in field plots under cropping and bare fallow. SSSA J. 46(6): 1212-1218.

Campbell, C. A., R. J. K. Myers, and K. L. Weier. 1981. Potentially mineralizable nitrogen, decomposition rates and their relationship to temperature for five Queensland soils. Australian J. Soil Res. 19(3): 323-332.

Cardoso, I., B. H. Janssen, O. Oenema, and T. W. Kuyper. 2003. Phosphorus pools in Oxisols under shaded and unshaded coffee systems on farmers' fields in Brazil. Agroforestry Systems 58(1): 55-64.

Chotte, J. L., C. Feller, J. M. Hetier, and A. Mariotti. 1998. The fate of fertilizer $\mathrm{N}$ in field studies in the volcanic Lesser Antilles with ${ }^{15} \mathrm{~N}$ urea. Tropical Agriculture (Trinidad) 75(3): 330-336.

Condron, L. M., J. O. Moir, H. Thiessen, and J. W. B. Stewart. 1990. Critical evaluation of methods for determining total organic phosphorus in tropical soils. SSSA J. 54(5): 1261-1266.

D'Andrea, A. F., M. L. N. Silva, N. Curi, and L. R. G. Guilherme. 2004. Estoque de carbono e nitrogenio e fotrmas de nitrogenio mineral em um solo submetido a diferentes sistemas de manejo. Pesquisa Agropecuaria Brasileira 39(2): 179-186.

Deare, F. M., N. Ahmad, and R. U. Ferguson. 1995. Downward movement of nitrate and ammonium nitrogen in a flatland Ultisol. Fertilizer Research 42: 175-184.

EPA. 2003. National management measures to control nonpoint-source pollution from agriculture. EPA 841-B-03-004. Washington, D.C.: U.S. Environmental Protection Agency.

Goncalves, J. L. M., R. F. Novais, N. F. Barros, J. C. L. Neves, and A. C. Ribeiro. 1989. Kinetics of transformation of labile and non-labile phosphorus in Cerrado soils. Revista Brasileira de Ciencia do Solo 13: 13-24. 
Guerra, J. G. M., D. L. Almeida, G. A. Santos, and M. S. Fernandes. 1996. Organic phosphorus content in soil samples. Pesquisa Agropecuaria Brasileira 31(4): 291-299.

Hartemink, A. E., R. J. Buresh, B. Jama, and B. H. Jansen. 1996. Soil nitrate and water dynamics in sesbania fallows, weed fallows, and maize. SSSA J. 60(2): 568-574.

Ipinmidun, W. B. 1973. Comparison of some methods for determining organic phosphorus in some Nigerian soils. Soil Sci. 115(4): 324-325.

ISRIC. 2003. ISRIC-WISE Global Soil Profile Data Set. Available at: www.isric.org/. Accessed 2 November 2004.

Knisel, W. G., and F. M. Davis. 1999. GLEAMS: Groundwater Loading Effects of Agricultural Management Systems, Version 3.0 User Manual. Pub. No. SEWRL-WGK/FMD-050199. Washington D.C.: U.S. Government Printing Office.

Lal, R. 1995. Sustainable Management of Soil Resources in the Humid Tropics. Tokyo, Japan: United Nations University Press.

Lopez, C. F., S. Vazquez, H. C. Dalurzo, and L. A. Morales. 2001. Index of phosphorus availability from fertilizer in soils of Misiones, Argentina. Agricultura Tecnica 61(2): 229-234.

Mekonnen, K., R. J. Buresh, and B. Jama. 1997. Root and inorganic nitrogen distribution in sesbania fallow, natural fallow and maize. Plant and Soil 188(2): 319-327.

Motavalli, P. P., C. A. Palm, D. D. Frey, and P. C. Smithson. 1995. Nitrogen mineralization in humid tropical forest soils: Mineralogy, texture, and measured nitrogen fractions. SSSA J. 59(4): 1168-1175.

Mubarak, A. R., A. B. Rosenani, S. Zauyah, and A. R. Anuar. 2001. Nitrogen mineralization in tropical soils amended with crop residues. Tropical Agric. 78(3): 165-173.

Neff, J. C., S. E. Hobbie, and P. M. Vitousek. 2000. Nutrient and mineralogical control on dissolved organic $\mathrm{C}, \mathrm{N}$, and $\mathrm{P}$ fluxes and stoichiometry in Hawaiian soils. Biochem. 51(3): 283-302.

Oberson, A., D. K. Friesen, I. M. Rao, S. Buhler, and E. Frossard. 2001. Phosphorus transformation in an Oxisol under contrasting land use systems: The role of the soil microbial biomass. Plant and Soil 237(2): 197-210.

O'Connel, A. M., and S. J. Rance. 1999. Predicting nitrogen supply in plantation of eucalypt forests. Soil Biol. and Biochem. 31(14): 1943-1951.

Phiri, S., E. Barrios, I. M. Rao, and B. R. Singh. 2001. Changes in soil organic matter and phosphorus fractions under planted fallows and crop rotation system on a Colombian volcanic-ash soil. Plant and Soil 231(2): 211-223.

Post, W. J., and J. Pastor. 1985. Global pattern of soil nitrogen storage. Nature 317(6038): 613-616.

Sampaio, E.V. S. B., I. H. Salcedo, M. A. Lima Jr, and J. Bettany. 1990. Decomposition of ${ }^{14} \mathrm{C}-{ }^{15} \mathrm{~N}$ straw incorporated at three depths in a red-yellow Latosol at Pernambuco State, Brazil. Revista Brasileira de Ciencia do Solo 14: 269-276.

Sanchez, P. A., M. P. Gichuru, and L. B. Katz. 1982. Organic matter in major soils of the tropical and temperate regions. In Proc. 12th Intl. Congress of Soil Science. New Delhi, India: ISSS, AISS, IBG.

San Jose, J. J., R. A. Montes, and C. Rocha. 2003. Neotropical savanna converted to food cropping and cattle feeding systems: Soil carbon and nitrogen changes over 30 years. Forest Ecology and Mgmt. 184: 17-32.
Sharpley, A. N., C. A. Jones, C. Gray, and C. V. Cole. 1984. A simplified soil and plant phosphorus model: II. Prediction of labile, organic, and sorbed phosphorus. SSSA J. 48(4): 805-809.

Sharpley, A. N., U. Singh, G. Uehara, and J. Kimble. 1989. Modeling soil and plant phosphorus dynamics in calcareous and highly weathered soils. SSSA J. 53(1): 153-158.

Shepherd G., R. J. Buresh, and P. J. Gregory. 2001. Inorganic soil nitrogen distribution in relation to soil properties in smallholder maize fields in the Kenya highlands. Geoderma 101(3-4): 87-103.

Sierra, J., N. Brisson, D. Ripoche, and C. Noel. 2003. Application of the STICS crop model to predict nitrogen availability and nitrate transport in a tropical acid soil cropped with maize. Plant and Soil 256(2): 333-345.

Silva, C. A. and F. R. Vale. 2000. Nitrate availability in Brazilian soils under effect of liming and sources and amounts of nitrogen. Pesquisa Agropecuaria Brasileira 35(12): 2461-2471.

Silva, C. L., M. M. Ramos, P. A. Ferreira, G. C. Sediyama, and B. T. Loureiro. 1994. Modeling the effective rainfall on maize. Pesquisa Agropecuaria Brasileira 29(6): 929-936.

Silva, M. A., J. C. A. Nobrega, N. Curi, J. O. Siqueira, J. J. G. S. M. Marques, and P. E. F. Motta. 2003. Phosphorus fractions in Oxisols. Pesquisa Agropecuaria Brasileira 38(10): 1197-1207.

Solomon, D., F. Fritzsche, J. Lehmann, M. Tekalign, and W. Zech. 2002. Soil organic matter dynamics in the subhumid agroecosystems of the Ethiopian highlands: Evidence from natural ${ }^{13} \mathrm{C}$ abundance and particle-size fractionation. SSSA $J$. 66(3): 969-978.

Stanford, G., and S. J. Smith. 1978. Oxidative release of potentially mineralizable soil nitrogen by acid permanganate extraction. Soil Sci. 126(4): 210-218.

Strong, D. T., P. W. G. Sale, and K. R. Helyar. 1998. The influence of the soil matrix on nitrogen mineralization and nitrification: I. Spatial variation and a hierarchy of soil properties. Australian J. Soil Res. 36(3): 429-447.

Tognon, A. A., J. L. I. Demate, and J. A. M. Demate. 1998. Teor e distribuicao da materia organica em latossolos das regioes da floresta amazonica e dos cerrados do Brasil central. Scientia Agricola 55(3): 343-354.

Tokura, A. M., A. E. Furtini Neto, N. Curi, V. Faquin, C. H. Kurihara, and A. A. Alves. 2002. Phosphorus forms on soils under no-till as a function of the depth and of cultivating time. Pesquisa Agropecuaria Brasileira 37(10): 1467-1476.

Van Wambeke, A. 2003. Properties and management of soils of the tropics. FAO Land and Water Digital Media Series No. 24. Rome, Italy: United Nations FAO.

Warren, G. P., and F. M. Kihanda. 2001. Nitrate leaching and adsorption in a Kenyan Nitisol. Soil Use and Mgmt. 17(4): 222-228.

Wild, A. 1972. Nitrate leaching under bare fallow at a site in northern Nigeria. European J. Soil Sci. 23(3): 315-324.

Wong, M. T. F., A. Wild, and A. S. R. Juo. 1987. Retarded leaching of nitrate measured in monolith lysimeters in south-east Nigeria. European J. Soil Sci. 38(3): 511-518. 
